\title{
Screening of Sunflower Genotypes for Potassium Use Efficiency in Irrigated Soil Condition
}

\author{
Sobia Baby Jamro, Naheed Akhtar Talpur, Mukesh Kumar Soothar*, \\ Zial ul Hassan Shah, Mahendar Kumar Sootahar and Ayaz Ali Panhwar \\ Department of Soil Science, Sindh Agriculture University, Tandojam, Pakistan \\ *mukeshksootar@gmail.com
}

Keywords: Sunflower, genotypes, K use efficiency

\begin{abstract}
A field experiment was conducted during summer 2016 to screen out sunflower (Helianthus annuus L.) genotypes for their potassium $(\mathrm{K})$ use efficiency ratio. Eight sunflower genotypes were tested; Samsung 20, Mehran 2, Ho-1, Melabour, Samsung 30, Valugur, Chinika and Sputnik in randomised complete block design (RCBD) with the two treatments comprised of potassium at 50 and $0 \mathrm{~kg} \mathrm{~K} \mathrm{ha}^{-1}$ along with source SOP recommended dose fertilizer respectively. The results revealed that the treated and control plots ( 50 and $0 \mathrm{~kg} \mathrm{~K} \mathrm{ha}^{-1}$ ) produced different values for of seeds (1763.1 and 1588.5 head ${ }^{-1}$ ), shoot dry weight (23.0 and $\left.19.11 \mathrm{~g}\right)$, head diameter (17.45 and $15.72 \mathrm{~cm}$ ), seed yields (2065.8 and $\left.1918.7 \mathrm{~kg} \mathrm{ha}^{-1}\right)$, seed $\mathrm{K} \%(0.60$ and $0.30 \%)$ and diagnostic tissue $\%$ (3.54 and 2.65\%) respectively. The considerable increase was found in seeds head ${ }^{-1}$ (10.99\%), shoot dry weight $(20.35 \%)$, head diameter $(11.01 \%)$, seed yields $(11.31 \%)$ seed K \% (100\%), and leaf K \% (33.58\%). Among genotypes, Ho-1 was highly effective added K fertilizer. The more seed $\left(2039.7\right.$ head $\left.^{-1}\right)$, shoot dry weight $(25.86 \mathrm{~g})$, head diameter $(20.20 \mathrm{~cm})$, seed yields $\left(2409.5 \mathrm{~kg} \mathrm{hat}^{-1}\right)$. Moreover seed $\mathrm{K} \%$ and leaf $\mathrm{K} \%$ was also high in variety $\mathrm{Ho}^{-1}(0.65 \%$ and $(5.05 \%)$ respectively. The Ho-1 genotype showed significant response to K fertilizer but the Ho- 1 and Chinika were more efficient in utilization of $\mathrm{K}$.
\end{abstract}

\section{Introduction}

Sunflower is a potential crop that can bridge the gap between oil consumption and supply locally [1]. Sunflower cultivation is well suited to the prevailing cropping as its cultivation does not replace major crops $[2,3]$. The oil received from the sunflower seed is favourable to human health containing vitamins A, D, E and K soluble vitamins [4, 5, 1]. In Pakistan, sunflower possesses the potential to overcome with the edible oil deficit and it is well adapted to existing agro-ecological conditions. There are many factors that are responsible for decline in soil fertility; and inefficient use of fertilizers is the major constraint for low productivity. Chemical fertilizers play a significant role in achieving higher crop yields [6]. The application of adequate fertilizers leads to enhance nutrient uptake in plant and nutrient balance in soil ultimately increasing production of crops [7]. Potassium $(\mathrm{K})$ is an essential nutrient not only for growth and root development of the plant but also in regulating the function of other macro and micronutrients. Due to potassium inadequacy, the plant resistance to insect pests, diseases and other natural hazards has been decreased; and horticultural crops are more at threat of soil borne diseases and other insect pest infestations [8]. The potassium levels of soils in Pakistan and particularly in Sindh province are going to be depleted day by day due to extensive cropping and high yielding varieties uptake substantially higher amounts of K to produce high yields [9]. So far there is no natural source to replenish it in to the soil; however due to its low levels in soils negative effects on crop yield and quality are seen in some parts of the country [10]. Supplementation of K-fertilizers is muriate of potash and sulphate of potash, the later one is a good source of potassium but it is very expensive and unfortunately farmers of Sindh province cannot afford it. Muriate of potash is cheaper source of potassium and also contains more $\mathrm{K}$ as compared to sulphate of potash but unluckily it contains chloride ion, which already exists in high quantity in soils of Sindh province due to arid and semi-arid climate. Therefore, with the application of muriate of potash, chloride level in the soil will increase to touch 
the climax and this more chloride will damage the crops instead of getting benefit and this may face heavy economic losses [11]. Sunflower needs $\mathrm{K}_{2} \mathrm{O}$ form $1.28 \%$ or in some cases 3.0 to $6.7 \%$ to produce desired crop yield [12]. It has been reported in study that the current yield level is very low as compared to the potential yield of many sunflower hybrids. Among various factors responsible for low yield, management of fertilizers may be of much importance [13]. Many researchers have observed and recommended that $75-100 \mathrm{~kg} \mathrm{~K} \mathrm{ha}^{-1}$ is profitable in terms of crop growth, high yield, seed yield, plant height and oil content under normal soil conditions [14-17]. Sivamurugan et al. [18] found that $40 \mathrm{~kg} \mathrm{ha}^{-1} \mathrm{~K}_{2} \mathrm{O}$ increased growth parameters and yield of the sunflower in the summer and spring seasons, respectively. Amanullah and Khan et al. [19] recommended $100 \mathrm{~kg}$ potash along with $45 \mathrm{~kg}$ of phosphorus; while Siddiqui et al. [20] suggested application of $45 \mathrm{~kg} \mathrm{ha}^{-1}$ to be the optimum fertilizer dose for sunflower growth and yield. Asadi [21] reported that the best yield was found in $200 \mathrm{~kg} \mathrm{ha}^{-1}$ level of $\mathrm{K}_{2} \mathrm{SO}_{4}$ treatment and the lowest yield was in the $50 \mathrm{~kg} \mathrm{ha}^{-1}$ of the $\mathrm{KCl}$ treatment.

Keeping in view the rapid mining of $\mathrm{K}$ from Pakistani soils, negligible $\mathrm{K}$ fertilization and high $\mathrm{K}$ requirement of sunflower, it is hypothesized that the modern high yielding and hybrid sunflower varieties may require an adequate supply of $\mathrm{K}$-fertilizer to offer optimum yield. This field study was carried out to evaluate the response of eight sunflower genotypes to apply fertilizer of potassium for their growth and yield. This study was based on screening of sunflower genotypes for potassium use efficiency ratio in irrigated soil condition of Tandojam.

\section{Materials and Methods}

The experiment was conducted during 2016-17 at the field of Oilseeds Section, Agriculture Research Institute Tandojam to evaluate the growth and yield response of eight sunflower genotypes to potassium fertilizer. The experimental block was divided into three main plots and further these were divided into eight sub-units of $3.0 \mathrm{~m} \times 5.0 \mathrm{~m}\left(15.0 \mathrm{~m}^{2}\right)$ with 03 replications. The seeds of eight sunflower genotypes; Samsung 20, Mehran-2, Ho-1, Melabour, Samsung 30, Valugur, Chinik, Sputnik were sown by drilling method in lines and after completion of germination, thinning was done to maintain $45 \mathrm{~cm}$ spacing between plant to plant and $60 \mathrm{~cm}$ spacing between rows.

The soil samples were collected at depths $0-45 \mathrm{~cm}$ and were brought to the laboratory of Plant Nutrition, Department of Soil Science, Sindh Agriculture University, Tandojam for analysis of physico-chemical properties and AB-DTPA extractable $\mathrm{K}$. The collected soil samples were analysed for EC by EC meter, organic matter by Walky and Black method, $\mathrm{pH}$ digital $\mathrm{pH}$ meter, Texture by Bouyoucos Hydrometer method and available $\mathrm{K}$ was determined by using flame photometer.

\section{Leaf/Seed $K$ contents}

After harvest, the sunflower leaves and seeds were separately obtained from the experimental field to determine leaf and seed $\mathrm{K}$ content from the treatments of all genotypes. The leaf and seed samples were determined by wet acid digestion. The samples were digested with nitric perchloric acid mixture (1:2). The digested samples were analyzed for $\mathrm{K}$ by using flame photometer.

\section{K-use efficiency ratio}

The K-use efficiency ratio was calculated according to the formula suggested by [22] Brar et al.

\section{Agronomic observations}

Following agronomic observations were recorded; seeds per head, head diameter $(\mathrm{cm})$, shoot dry weight $(\mathrm{g})$ and seeds yield $\left(\mathrm{kg} \mathrm{ha}^{-1)}\right.$. 


\section{Statistical analysis}

The data thus collected were statistically analysed using Statistix ver. 8.1. The ANOVA was derived to examine the significance of treatment effect; while the LSD test was applied to compare the mean values for assessing significance effect among treatments.

\section{Results}

In order to screen out some sunflower genotypes for potassium $(\mathrm{K})$ use efficiency ratio. Agronomic parameters and soil analysis including leaf and seed $\mathrm{K}$ content was examined. In control plots the genotypes were fertilized with NPK@100-50-0 kg ha ${ }^{-1}$; while in treatment plots, the experimental crop was fertilized with NPK @100-50-50 kg ha ${ }^{-1}$. The experiment revealed the following results.

\section{Shoot dry weight (g)}

The data regarding shoot dry weight (Table-1) shows that the analysis of variance depicted that the treatment effect on shoot dry weight was significant $(\mathrm{P}<0.05)$ and sunflower genotypes also varied $(\mathrm{P}<0.05)$ for shoot dry weight. However, interactive effect of treatments and genotypes was insignificant on shoot dry weight $(\mathrm{P}>0.05)$. The addition of $\mathrm{K}\left(100-50-50 \mathrm{~kg} \mathrm{ha}^{-1} \mathrm{NPK}\right)$ resulted in higher shoot dry weight (23.20 g) as compared to $19.11 \mathrm{~g}$ under recommended fertilizer application of $100 \mathrm{~kg} \mathrm{~N}$ and $50 \mathrm{~kg} \mathrm{ha}^{-1} \mathrm{P}$ (Control). The increase in shoot dry weight in treated plots was 20.35 percent over control. The variety response showed that Ho-1 produced maximum shoot dry weight $(25.86 \mathrm{~g})$, followed by genotypes Mehran 2, Sputnik and Chinika with average shoot dry weight of 23.49, 22.72 and $20.77 \mathrm{~g}$, respectively. However, the lowest shoot dry weight (18.73 g) was recorded in genotype Valugur.

Table 1. Shoot dry weight (g) of sunflower genotypes as affected by K fertilizer

\begin{tabular}{|c|c|c|c|c|}
\hline \multirow[b]{2}{*}{ S. No. } & \multirow[b]{2}{*}{ Genotypes } & \multicolumn{2}{|c|}{ Treatments } & \multirow[b]{2}{*}{$\begin{array}{l}\text { Mean for } \\
\text { genotypes }\end{array}$} \\
\hline & & $\begin{array}{c}\text { Control } \\
\left.\text { (NPK } @ 100-50-0 \mathrm{~kg} \mathrm{ha}^{-1}\right)\end{array}$ & $\begin{array}{c}\text { Treatment } \\
\left(\text { NPK } @ 100-50-50 \mathrm{~kg} \mathrm{ha}^{-1}\right)\end{array}$ & \\
\hline 1 & Samsung 20 & 17.64 & 20.38 & $19.01^{\mathrm{DE}}$ \\
\hline 2 & Mehran 2 & 20.95 & 26.33 & $23.49^{B}$ \\
\hline 3 & Ho-1 & 23.20 & 28.53 & $25.86^{A}$ \\
\hline 4 & Melabour & 17.40 & 20.65 & $19.03^{\mathrm{DE}}$ \\
\hline 5 & Samsung 30 & 17.64 & 20.44 & $19.01^{\mathrm{DE}}$ \\
\hline 6 & Valugur & 17.15 & 20.30 & $18.73^{E}$ \\
\hline 7 & Chinika & 18.84 & 22.70 & $20.77^{\mathrm{CD}}$ \\
\hline 8 & Sputnik & 20.46 & 24.98 & $22.72^{\mathrm{BC}}$ \\
\hline \multicolumn{2}{|c|}{ Mean for treatments } & $19.11^{B}$ & $23.00^{A}(20.35 \%)$ & - \\
\hline
\end{tabular}

\section{Head diameter (cm)}

The (Table 2) analysis of variance in regards to sunflower head diameter suggested that addition of potash fertilizer significantly affect the head diameter $(\mathrm{P}<0.05)$; and genotypes effect on this trait was also significant $(\mathrm{P}<0.05)$; while the interactive effect of treatments and genotypes was insignificant $(\mathrm{P}>0.05)$ on head diameter. The results (Table 2$)$ showed that addition of $\mathrm{K}\left(50 \mathrm{~kg} \mathrm{ha}^{-1}\right)$ produced sunflower heads of greater diameter $(17.45 \mathrm{~cm})$ as compared to $(15.72 \mathrm{~cm})$ in control given recommended fertilizer (100-50-0 kg ha $\left.{ }^{-1} \mathrm{NPK}\right)$. The increase in head diameter in treatment plots (100-50-50 kg ha $\left.{ }^{-1} \mathrm{NPK}\right)$ was 11.01 percent over control. The varietal response indicated that sunflower variety HO-1 produced heads of maximum diameter $(20.20 \mathrm{~cm})$, followed by genotypes 
Mehran 2, Sputnik and Chinika with average head diameter of $18.24,17.46$ and $16.74 \mathrm{~cm}$, respectively. However, the minimum head diameter $(14.93 \mathrm{~cm})$ was recorded in genotypes Valugur. Sunflower genotypes Samsung 20, Melabour and Samsung 30 showed similarity in head diameter $(\mathrm{P}>0.05)$. The interactive effect showed that the maximum head diameter $(21.25 \mathrm{~cm})$ was recorded in variety HO-1 when treated with additional $50 \mathrm{~kg} \mathrm{~K} \mathrm{ha}^{-1}$ while genotype valugur at control remained lowest in head diameter $(14.15 \mathrm{~cm})$.

Table 2. Head diameter $(\mathrm{cm})$ of sunflower genotypes as affected by $\mathrm{K}$ fertilizer

\begin{tabular}{|c|c|c|c|c|}
\hline \multirow[b]{2}{*}{ S. No. } & \multirow[b]{2}{*}{ Genotypes } & \multicolumn{2}{|c|}{ Treatments } & \multirow[b]{2}{*}{$\begin{array}{l}\text { Mean for } \\
\text { genotypes }\end{array}$} \\
\hline & & $\begin{array}{c}\text { Control } \\
(\text { NPK @100-50-0 kg ha-1) }\end{array}$ & $\begin{array}{c}\text { Treatment } \\
\left(\text { NPK@100-50-50 kg ha }{ }^{-1}\right)\end{array}$ & \\
\hline 1 & Samsung 20 & 14.20 & 15.76 & $14.98^{D}$ \\
\hline 2 & Mehran 2 & 17.29 & 19.19 & $18.24^{\mathrm{B}}$ \\
\hline 3 & Нo-1 & 19.14 & 21.25 & $20.20^{A}$ \\
\hline 4 & Melabour & 14.36 & 15.94 & $15.15^{\mathrm{D}}$ \\
\hline 5 & Samsung 30 & 14.23 & 15.80 & $15.02^{\mathrm{D}}$ \\
\hline 6 & Valugur & 14.15 & 15.71 & $14.93^{D}$ \\
\hline 7 & Chinika & 15.87 & 17.62 & $16.74^{C}$ \\
\hline 8 & Sputnik & 16.55 & 18.37 & $17.46^{\mathrm{BC}}$ \\
\hline \multicolumn{2}{|c|}{ Mean for treatments } & $15.72^{\mathrm{B}}$ & $17.45^{\mathrm{A}}(11.01 \%)$ & - \\
\hline
\end{tabular}

\section{Seeds head ${ }^{-1}$}

The (Table 3) statistical analysis describes significant variation in the number of seeds head ${ }^{-1}$ due to addition of $\mathrm{K}$ source (SOP) in addition to recommended fertilizer application $(\mathrm{P}<0.05)$ and genotypes of diversified origin also responded differently to $\mathrm{K}$ addition to fertilizer dose $(\mathrm{P}<0.05)$, However, insignificant interactive effect of treatment and genotypes $(\mathrm{P}>0.05)$ was recorded. The treatment comprised of $\mathrm{K}$ addition resulted in an increased number of seeds $\left(1080.7 \mathrm{head}^{-1}\right)$ over control where the number of seeds declined to $(1064.7)$ head $^{-1}$. The increase in seeds head ${ }^{-1}$ in treatment plots (K addition) was 10.99 percent over control. The varietal response showed that Ho- 1 produced maximum number of seeds $\left(1482.0 \mathrm{head}^{-1}\right)$, followed by genotypes Mehran 2, Sputnik and Chinika with 1282.71208 .7 and 1060.7 seed head $^{-1}$, respectively. However, the lowest number of seeds (803.0 head ${ }^{-1}$ ) was recorded in Valugur. Sunflower genotypes Samsung 20, Melabour, and Samsung 30 showed similarity $(\mathrm{P}>0.05)$ in number of seeds head ${ }^{-1}$. The interactive effect showed that the highest number of seeds $\left(1484.0\right.$ head $\left.^{-1}\right)$ was recorded in variety Ho-1 with recommended fertilizers; while genotypes valugur in control remained least for number of seeds (793.3 head $\left.{ }^{-1}\right)$.

Table 3. Seeds per head of sunflower genotypes as affected by K fertilizer

\begin{tabular}{|c|l|c|c|c|}
\hline \multirow{2}{*}{ S. No. } & \multirow{2}{*}{ Genotypes } & $\begin{array}{c}\text { Control } \\
\text { (NP@100-50 kg ha }\end{array}$ & \multirow{2}{*}{$\begin{array}{c}\text { Treatments } \\
\text { (NPK @100-50-50 kg ha }\end{array}$} & $\begin{array}{c}\text { Treatment } \\
\text { genotypes }\end{array}$ \\
\hline 1 & Samsung 20 & 1434.3 & 1591.9 & $\mathbf{1 5 1 3 . 1}^{\text {E }}$ \\
\hline 2 & Mehran 2 & 1746.4 & 1938.8 & $\mathbf{1 8 4 2 . 6}^{\text {B }}$ \\
\hline 3 & Ho-1 & 1933.5 & 2145.9 & $\mathbf{2 0 3 9 . 7}^{\mathbf{A}}$ \\
\hline 4 & Melabour & 1450.4 & 1609.9 & $\mathbf{1 5 3 0 . 1}^{\text {DE }}$ \\
\hline 5 & Samsung 30 & 1437.9 & 1596.1 & $\mathbf{1 5 1 7 . 0}^{\text {E }}$ \\
\hline 6 & Valugur & 1429.8 & 1587.1 & $\mathbf{1 5 0 8 . 5}^{\text {E }}$ \\
\hline 7 & Chinika & 1570.3 & 1779.7 & $\mathbf{1 6 7 5 . 0}^{\text {CD }}$ \\
\hline 8 & Sputnik & 1705.1 & 1855.6 & $\mathbf{1 7 8 0 . 3}^{\text {BC }}$ \\
\hline \multicolumn{2}{|l}{ Mean for treatments } & $\mathbf{1 5 8 8 . 5}$ & $\mathbf{1 7 6 3 . 1}^{\mathbf{A}}(\mathbf{1 0 . 9 9 \% )}$ & - \\
\hline
\end{tabular}




\section{Seeds yield $\left(\mathrm{kg} \mathrm{ha}^{-1}\right)$}

The (Table 4) ANOVA related to the data on sunflower seed yield $\mathrm{kg} \mathrm{ha}^{-1}$ describes that application of potash resulted in a significant effect on seed yield $\mathrm{kg} \mathrm{ha}^{-1}(\mathrm{P}<0.05)$; and sunflower genotypes included in this experiment responded variably for seeds yield $\mathrm{kg} \mathrm{ha}^{-1}(\mathrm{P}<0.05)$; whereas the interactive effect of applied $\mathrm{K}$ fertilizer and genotypes was insignificant $(\mathrm{P}>0.05)$ on seeds yield $\mathrm{kg} \mathrm{ha}^{-1}$. The data indicated that treatment plots $\left(50 \mathrm{~kg} \mathrm{~K} \mathrm{ha}^{-1}\right)$ produced significantly higher sunflower seeds yields $\left(2065.8 \mathrm{~kg} \mathrm{ha}^{-1}\right)$ as compared to those in control where $1918.7 \mathrm{~kg} \mathrm{ha}^{-1}$ seeds yield was obtained. The treatment plots $\left(50 \mathrm{~kg} \mathrm{ha}^{-1}\right)$ increased 11.31 percent of seeds yield $\mathrm{kg} \mathrm{ha}^{-1}$ over control. Among the varieties, HO-1 produced higher seeds yield ( $\left.2473 \mathrm{~g} \mathrm{~kg} \mathrm{ha}^{1}\right)$. However, the lowest seeds yield $\left(1720 \mathrm{~g} \mathrm{~kg} \mathrm{ha}^{-1}\right)$ was achieved in valugur. The treatment interaction indicated that maximum seeds yield $\left(2573 \mathrm{~g} \mathrm{~kg} \mathrm{ha}^{-1}\right)$ was achieved from variety $\mathrm{HO}^{-1}$ with the addition $\left(50 \mathrm{~kg} \mathrm{~K} \mathrm{ha}^{-1}\right)$; while genotypes valugur remained lowest in seeds yield $\left(1906 \mathrm{~g} \mathrm{~kg} \mathrm{ha}^{-1}\right)$.

Table 4. Seeds yield $\left(\mathrm{kg} \mathrm{ha}^{-1}\right)$ of sunflower genotypes as affected by $\mathrm{K}$ fertilizer

\begin{tabular}{|c|c|c|c|c|}
\hline \multirow[b]{2}{*}{ S. No. } & \multirow[b]{2}{*}{ Genotypes } & \multicolumn{2}{|c|}{ Treatments } & \multirow[b]{2}{*}{$\begin{array}{l}\text { Mean for } \\
\text { genotypes }\end{array}$} \\
\hline & & $\begin{array}{c}\text { Control } \\
\left(\mathrm{NPK} @ 100-50-0 \mathrm{~kg} \mathrm{ha}^{-1}\right)\end{array}$ & $\begin{array}{c}\text { Treatment } \\
\left(\text { NPK } @ 100-50-50 \mathrm{~kg} \mathrm{ha}^{-1}\right)\end{array}$ & \\
\hline 1 & Samsung 20 & 1713 & 1900 & $1806.5^{\mathrm{C}}$ \\
\hline 2 & Mehran 2 & 2046 & 2226 & $2136^{B}$ \\
\hline 3 & Ho-1 & 2246 & 2573 & $2409.5^{A}$ \\
\hline 4 & Melabour & 1740 & 1933 & $1836.5^{C}$ \\
\hline 5 & Samsung 30 & 1726 & 1913 & $18.19 .5^{C}$ \\
\hline 6 & Valugur & 1720 & 1906 & $1813^{\mathrm{C}}$ \\
\hline 7 & Chinika & 2133 & 1886 & $2009.5^{B}$ \\
\hline 8 & Sputnik & 2026 & 2190 & $2108^{B}$ \\
\hline \multicolumn{2}{|c|}{ Mean for treatments } & $1918.7^{B}$ & $2065.8^{A}(11.31 \%)$ & - \\
\hline
\end{tabular}

\section{Leaf K (\%)}

The (Table 5) analysis of variance for the data on leaf K-uptake showed that the effect of $\mathrm{K}$ addition (NPK 100-50-50 $\mathrm{kg} \mathrm{ha}^{-1}$ ) was significant on leaf $\mathrm{K} \%$, and genotypes of diversified origin also showed varied leaf $\mathrm{K} \%$. However, treatment $\times$ genotypes interaction was insignificant $(\mathrm{P}>0.05)$ on leaf $\mathrm{K} \%$. The results indicated that the addition of $\mathrm{K}$ resulted in increased leaf $\mathrm{K} \%$ (3.54\%) as compared to $2.65 \%$ leaf $\mathrm{K} \%$ determined in crop given control fertilizers. The leaf $\mathrm{K} \%$ in treatment plots was 33.58 percent higher over control. The genotypes effect indicated that the leaf $\mathrm{K} \%$ was higher in variety Ho-1 (5.05\%), followed by genotypes Chinika, Mehran-2 Sputnik and Melabour with average leaf K-uptake of 3.50, 3.15, 3.15 and 3.00 percent, respectively. However, the lowest leaf $\mathrm{K}$ percent $(2.30 \%)$ was determined equally in genotypes valugur, Samsung 30 and Samsung 20. These results indicate that addition of $K$ in the fertilizer was beneficial for leaf K-uptake of sunflower. 
Table 5. Leaf K (\%) of sunflower genotypes as affected by K fertilizer

\begin{tabular}{|c|c|c|c|c|}
\hline \multirow[b]{2}{*}{ S. No. } & \multirow[b]{2}{*}{ Genotypes } & \multicolumn{2}{|c|}{ Treatments } & \multirow[b]{2}{*}{$\begin{array}{l}\text { Mean for } \\
\text { genotypes }\end{array}$} \\
\hline & & $\begin{array}{c}\text { Control } \\
\left(\text { NPK@100-50-0 kg ha }{ }^{-1}\right)\end{array}$ & $\begin{array}{c}\text { Treatment } \\
\left(\text { NPK@100-50-50 kg ha }{ }^{-1}\right)\end{array}$ & \\
\hline 1 & Samsung 20 & 2.00 & 2.60 & $2.30^{C}$ \\
\hline 2 & Mehran 2 & 2.30 & 4.00 & $3.15^{\mathrm{BC}}$ \\
\hline 3 & Ho-1 & 4.70 & 5.40 & $5.05^{\mathrm{A}}$ \\
\hline 4 & Melabour & 3.00 & 3.00 & $3.00^{\mathrm{BC}}$ \\
\hline 5 & Samsung 30 & 1.60 & 3.00 & $2.30^{\mathrm{C}}$ \\
\hline 6 & Valugur & 2.00 & 2.60 & $2.30^{C}$ \\
\hline 7 & Chinika & 3.30 & 3.70 & $3.50^{B}$ \\
\hline 8 & Sputnik & 2.30 & 4.00 & $3.15^{\mathrm{BC}}$ \\
\hline \multicolumn{2}{|c|}{ Mean for treatments } & $2.65^{B}$ & $3.54^{\mathrm{A}}(33.58 \%)$ & - \\
\hline
\end{tabular}

\section{Seed K (\%)}

The (Table 6) analysis of variance for the data on seed K-uptake indicated that the effect of $\mathrm{K}$ $50 \mathrm{~kg} \mathrm{~K} \mathrm{ha}{ }^{-1}$ was significant on seed $\mathrm{K} \%$, while the effect of genotypes and treatment genotype interaction was also significant on seed $\mathrm{K} \%(\mathrm{P}<0.05)$. The data showed that the addition of $\mathrm{K}$ $\left(50 \mathrm{~kg} \mathrm{~K} \mathrm{ha}{ }^{-1}\right)$ resulted in higher seed $\mathrm{K} \%(0.60 \%)$ as compared to $0.30 \%$ seed $\mathrm{K}$-uptake recorded in crop. The seed $\mathrm{K} \%$ in treatment plots was 100 percent higher over control. The genotypes effect showed that the seed K-uptake was higher in variety Hol $(0.65 \%)$, followed by genotypes Mehran 2, Sputnik and Chinika with average seed $\mathrm{K} \%$ of $0.60,0.55$ and 0.45 percent, respectively. However, the lowest seed K \% (0.25\%) was determined in genotypes Mehran-2 Samsung 20. The treatment and genotypes interaction indicated that the highest seed $\mathrm{K}$ percentage $(0.8 \%)$ was determined equally in varieties Ho-1 and genotypes, Mehran 2 sown under NPK fertilizers dose; while the minimum seed $\mathrm{K}$ percentage $(0.1 \%)$ was recorded in genotypes 30 , Samsung 20 and Melabour grown in control. This result indicates that addition of $\mathrm{K}$ in the fertilizer was beneficial for seed K-content of sunflower.

Table 6. Seed K (\%) of sunflower genotypes as affected by K fertilizer

\begin{tabular}{|c|l|c|c|c|}
\hline \multirow{2}{*}{ S. No. } & \multirow{2}{*}{ Genotypes } & $\begin{array}{c}\text { Control } \\
\text { Treatments }\end{array}$ & \multirow{2}{*|}{$\begin{array}{c}\text { Mean for } \\
\text { genotypes }\end{array}$} \\
\hline 1 & Samsung 20 & 0.1 & 0.4 & $0.25^{\mathrm{G}}$ \\
\hline 2 & Mehran 2 & 0.1 & 0.8 & $0.25^{\mathrm{G}}$ \\
\hline 3 & Ho-1 & 0.5 & 0.8 & $0.65^{\mathrm{A}}$ \\
\hline 4 & Melabour & 0.1 & 0.7 & $0.4^{\mathrm{E}}$ \\
\hline 5 & Samsung 30 & 0.4 & 0.4 & $0.4^{\mathrm{E}}$ \\
\hline 6 & Valugur & 0.3 & 0.3 & $0.3^{\mathrm{F}}$ \\
\hline 7 & Chinika & 0.4 & 0.7 & $0.55^{\mathrm{C}}$ \\
\hline 8 & Sputnik & 0.5 & 0.7 & $0.6^{\mathrm{B}}$ \\
\hline \multicolumn{2}{|c|}{ Mean for treatments } & $\mathbf{0 . 3}$ & $\mathbf{0 . 6}^{\mathbf{A}} \mathbf{( 1 0 0 . 0 0 \% )}$ & - \\
\hline
\end{tabular}

\section{K-use efficiency ratio}

The K-use efficiency ratio of different sunflower genotypes with addition of potash at the rate of $50 \mathrm{~kg} \mathrm{ha}^{-1}$ was calculated and statistical analysis (Table 7) suggested a significant $(\mathrm{P}<0.05)$ treatment impact on the K-use efficiency ratio of sunflower genotypes over control. The results showed that the highest $\mathrm{K}$-use efficiency ratio calculates in $\mathrm{kg} \mathrm{ha}^{-1}\left(653 \mathrm{~kg} \mathrm{ha}^{-1}\right)$ was determined 
sunflower genotype HO-1, followed by genotypes Chinika, and Melabour, with K-use efficiency ratio of $493 \mathrm{~kg} \mathrm{ha}^{-1}, 386 \mathrm{~kg} \mathrm{ha}^{-1}$ and $375 \mathrm{~kg} \mathrm{ha}^{-1}$ respectively. However, the lower K-use efficiency ratio of $360 \mathrm{~kg} \mathrm{ha}^{-1}$ and $333 \mathrm{~kg} \mathrm{ha}^{-1}$ was determined in sunflower genotypes Mehran-2 and Sputnik, respectively. This indicates that with use of $\mathrm{K}\left(50 \mathrm{~kg} \mathrm{ha}^{-1}\right)$ all the sunflower tested genotypes showed significant response to applied $\mathrm{K}$, but variety Ho-1 and genotypes Chinika and Melabour were more efficient in utilization of applied $\mathrm{K}$.

Table 7. K-use efficiency ratio of sunflower genotypes as affected by potash fertilizer

\begin{tabular}{|c|c|c|c|c|}
\hline \multirow[b]{2}{*}{ S. No. } & \multirow[b]{2}{*}{ Genotypes } & \multicolumn{3}{|c|}{ Treatments } \\
\hline & & $\begin{array}{c}\text { Control } \\
(\mathrm{NPK} @ 100-50-0 \mathrm{~kg} \\
\left.\text { ha }^{-1}\right) \\
\end{array}$ & $\begin{array}{c}\text { Treatment } \\
(\mathrm{NPK} @ 100-50-50 \mathrm{~kg} \\
\left.\text { ha }^{-1}\right)\end{array}$ & KUE \\
\hline 1 & Samsung 20 & 1713 & 1900 & $374^{\mathrm{C}}$ \\
\hline 2 & Mehran 2 & 2046 & 2226 & $360^{B}$ \\
\hline 3 & Ho-1 & 2246 & 2573 & $654^{A}$ \\
\hline 4 & Melabour & 1740 & 1933 & $386^{C}$ \\
\hline 5 & Samsung 30 & 1726 & 1913 & $374^{C}$ \\
\hline 6 & Valugur & 1720 & 1906 & $372^{C}$ \\
\hline 7 & Chinika & 2133 & 1886 & $494^{B}$ \\
\hline 8 & Sputnik & 2026 & 2190 & $328^{B}$ \\
\hline \multicolumn{2}{|c|}{ Mean for treatments } & $1918.75^{B}$ & $2065.8^{A}(11.31 \%)$ & \\
\hline
\end{tabular}

\section{Discussion}

Sunflower genotypes Samsung 20, Mehran 2, Ho-1, Melabour, Samsung 30, valugur, Chinika and Sputnik were planted under field conditions to screen out for potassium use efficiency ratio and these varieties were examined for certain agronomic parameters as well as for seed and leaf $\mathrm{K}$ percentage. The treatments were comprised of NPK @100-50-50 kg ha ${ }^{-1}$; with control (NPK@100$50-0 \mathrm{~kg} \mathrm{ha}^{-1}$ ). The findings of the study are discussed in this section.

The findings of the study show that sunflower growth and yield performance was significantly variable due to the addition of $\mathrm{K}$. The treated plots and control plots produced different values for number of seeds (1763.1 and $\left.1588.5 \mathrm{head}^{-1}\right)$, shoot dry weight $(23.0$ and $19.11 \mathrm{~g})$, head diameter $(17.45$ and $15.72 \mathrm{~cm})$, seeds yields $\left(2065.8\right.$ and $\left.1918.8 \mathrm{~kg} \mathrm{ha}^{-1}\right)$, seed $\mathrm{K}$ percentage $(0.60$ and 0.30 and leaf percentage (3.54 and 2.65\%). There was a considerable increase in seeds head ${ }^{-1}$ (10.99\%), shoot dry weight $(20.35 \%)$, head diameter $(11.01 \%)$, seed yields $(11.31 \%)$, seed $\mathrm{K}$ percentage $(100 \%)$, leaf $\mathrm{K}$ percentage $(33.58 \%)$. Among varieties, Ho-1 was highly efficient to utilize added $\mathrm{K}$ level with more shoot dry weight $(25.86 \mathrm{~g})$, seeds $\left(2039.7 \mathrm{head}^{-1}\right)$, head diameter $(20.20 \mathrm{~cm})$, seeds, yields $\left(2409.5 \mathrm{~g} \mathrm{~kg} \mathrm{ha}^{-1}\right)$, while seed $\mathrm{K} \%$ was higher in Ho1 $(0.65 \%)$ and leaf $\mathrm{K}$ percent was highest in variety Ho-1 (5.05\%). Agronomic performance and seed/plant K \% of sunflower significantly improved with addition of potash. The genotypes of diversified origin responded variably to potash application for agronomic performance and seed/plant $\mathrm{K}$ and $\mathrm{K}$-use efficiency ratio of different sunflower genotypes with addition of potash at the rate of $50 \mathrm{~kg} \mathrm{ha}^{-1}$ was significant $(\mathrm{P}<0.05)$ impact on the $\mathrm{K}$-use efficiency ratio of sunflower genotypes over control.

The results of the present study are in agreement with those of many past workers who have worked in different parts of the world on similar aspects. $[14,15,16]$ reported that increase in leaf area, plant height, stem girth, head diameter, number of achenes head ${ }^{-1}, 1000$-achenes weight, harvest index and oil content of sunflower, yield with $100 \mathrm{~kg} \mathrm{~K}_{2} \mathrm{O} \mathrm{ha}^{-1}$. [17] achieved highest seed yield of $2.235 \mathrm{t} \mathrm{ha}^{-1}$ by applying $75 \mathrm{~kg} \mathrm{~K} \mathrm{ha}^{-1}$ and $75-100 \mathrm{~kg} \mathrm{~K} \mathrm{ha}^{-1}$ was considered as the optimum level, beyond this level the application of potash is not profitable. [23] indicated that the highest 1000 -seed weight (53.71g) was obtained from the plot fertilized with $150 \mathrm{~kg} \mathrm{~K} \mathrm{ha}^{-1}$, while the 
minimum 1000-seed weight (46.41g) was obtained in control plots. [24] recommended $50 \mathrm{~kg} \mathrm{ha}^{-1} \mathrm{~K}$ in addition to $80 \mathrm{~kg} \mathrm{~N}$ and $50 \mathrm{~kg} \mathrm{ha}^{-1}$; while [18] found that $\mathrm{K}$ at $40 \mathrm{~kg} \mathrm{ha}^{-1}$ gave the highest values of head diameter (15.3 and $13.6 \mathrm{~cm})$, number of seeds per head (655 and 585), 100-seed weight (5.24 and $5.20 \mathrm{~g}$ ) and seed yield (1540 and $1313 \mathrm{~kg}$ ha) in the summer and SWM season, respectively. In a similar investigation, [25] reported that $90 \mathrm{~kg} \mathrm{~K} \mathrm{ha}^{-1}$ was found to be most effective $\mathrm{K}$ rate in combination with recommended $\mathrm{N}$ and $\mathrm{P}$ fertilizers, they suggested that $60 \mathrm{~kg} \mathrm{~K}$ in addition to $120 \mathrm{~kg} \mathrm{~N}$ and $90 \mathrm{~kg} \mathrm{P} \mathrm{ha}^{-1}$ as optimum fertilizer levels for sunflower crop under the experimental conditions. [26] achieved highest seed yield (1231.47 $\mathrm{kg} \mathrm{ha}^{-1}$ ) with 130-90-90 kg NPK ha treatment; and from India [27] reported that $120 \mathrm{~kg} \mathrm{~K}$ in addition to $90 \mathrm{~kg} \mathrm{~N} \mathrm{ha}^{-1}$ and $120 \mathrm{~kg} \mathrm{P}_{2} \mathrm{O}_{5}$ $\mathrm{ha}^{-1}$ were found to be an effective and efficient combination for achieving higher seed yields and oil content in tested sunflower variety. Amanullah and Khan [19] reported that $100 \mathrm{~kg}$ potash along with $45 \mathrm{~kg}$ of phosphorus per hectare was most effective combination of $\mathrm{P}$ and $\mathrm{K}$ in addition to uniform rate of nitrogen. [20] proved the incorporation of $90-45-45 \mathrm{~kg} \mathrm{ha}^{-1}$ as optimum fertilizer dose for sunflower growth and yield. Chajjro et al. [11] noted that adequate $\mathrm{K}$ nutrition $\left(120 \mathrm{~kg} \mathrm{~K} \mathrm{ha}{ }^{-1}\right)$ enhanced the growth and achene yield of both sunflower hybrids even under adequate soil $\mathrm{K}$ condition. Mollashahi and Fanaei [28] indicated that use of potassium fertilizers improves quantitative and qualitative characteristics of sunflower. Memon [29] concluded that the sunflower crop splendid performance when supplied with N-P fertilizers at the rate of 150-100 kg $\mathrm{ha}^{-1}$ with highest yield and oil content along with $50 \mathrm{~kg} \mathrm{ha}^{-1} \mathrm{~K}$ in the form of MOP. The study of [30] showed that maximum seed yield $\left(2813 \mathrm{~kg} \mathrm{ha}^{-1}\right)$ was produced by fertilizer combinations of 150:100:100 NPK kg ha ${ }^{-1}$ and minimum in control plot $\left(1813 \mathrm{~kg} \mathrm{ha}^{-1}\right)$. The new genotypes responded variably to $\mathrm{K}$ application for agronomic performance and seed/plant K-uptakes; and screening of new lines for K use efficiency showed that Ho-1, Mehran-2, Chinika and Sputnik are most promising genotypes that possess significant potash use efficiency to convert it into increased seed yield. The K uptake was also markedly higher in genotypes Mehran-2, Chinika and Sputnik and these genotypes could be the future potential genotype. Similar results have been reported by many research workers. [24] revealed that $\mathrm{K}$ use efficiency of sunflower genotypes varied significantly and there was no relation of increased $\mathrm{K}$ uptake by leaf or seed with the yield level of genotypes. [31] reported that the $\mathrm{K}$ application had significant impact yield attributes of sunflower genotypes and local genotypes showed simultaneously development in $\mathrm{K}$ use efficiency and increased yield compared to the hybrids. [25] reported that application of potash to sunflower had significant impact on crop performance, but the varietal response to $\mathrm{K}$ application levels varied considerably. There was no linear relationship of $\mathrm{K}$ uptakes with the seed yields. [28] grown a set of sunflower cultivars and after screening test it was observed that (cv. MSFH-8) variety responded $120 \mathrm{~kg} \mathrm{~K}$ positively with increasing seed yield and plant uptakes. [21] applied $\mathrm{K}_{2} \mathrm{SO}_{4}$ at the rate of $200 \mathrm{~kg} \mathrm{ha}^{-1}$ in addition to $\mathrm{N}$ and $\mathrm{P}$ at the recommended levels for particular soils and found that sunflower varieties responded positively to increased $\mathrm{K}$ rates upto $100 \mathrm{~kg} \mathrm{ha}^{-1}$, further increase in $\mathrm{K}$ results adverse effect on the crop yields and plant uptakes. Most of the hybrids responded positively to increased $\mathrm{K}$ rates, but $\mathrm{K}$ up to $100 \mathrm{~kg} \mathrm{ha}^{-1}$ could be beneficially applied, because further increase in $\mathrm{K}$ resulted in negative effects on yield of all the varieties tested. [30] used sunflower hybrids (SF187 and Parsun-1) against various $\mathrm{K}$ levels and found varied response of sunflower hybrids to increased K levels, However, a combination of 150:100:100 kg ha ${ }^{-1}$ NPK resulted in optimistic results regarding agronomic performance and plant nutrient uptakes. [32] evaluated the impact of potassium use efficiency of sunflower hybrids and found that Helio 251 had higher potassium use efficiency as compared to rest of the hybrids.

\section{Conclusion}

The present study has been concluded that the sunflower genotypes performed the best against potassium fertilizer dose. It was observed that variety HO-1, or genotypes Chinika and Melabour are most promising genotypes that possess significant potash use efficiency ratio to convert it into increased seed yield. 


\section{Conflict of Interest}

The authors declare that there is no conflict of interest.

\section{References}

[1] H. Nezami et al., Effect of drought stress and defoliation on sunflower (Helianthus annuus L.) in controlled conditions, Desert. 12 (2008) 99-104.

[2] M.S.A. Ahmad et al., Photosynthetic performance of two mungbean (Vigna radiata) cultivars under lead and copper stress, Int. J. Agric. Biol. 10 (2009) 167-172.

[3] V.S. Rathore, R.C. Gautam, S.K. Kaushik, Yield, quality and nutrient uptake by sunflower as influenced by weed and nutrient management, J. Annals Agric. Res. 22(3) (2001) 443-444.

[4] M.K. Hussain, E. Rasul, S.K. Ali, Growth analysis of sunflower under drought conditions, Int. J. Agric. Biol. 2 (2000) 136-140.

[5] H. Razi, M.T. Asad, Evaluation of variation of agronomic traits and water stress tolerant in sunflower conditions, Agric. Natural Res. Sci. 2 (1998) 31-43.

[6] T.I. Hussain, M.A. Ahmed, EM Technology-A new looks for IPNM, in: Proc. Symp., Integrated Plant Nutrient Management, NFDC, Islamabad, Pakistan, 2000.

[7] J.A. Adediran et al., Application of organic and inorganic fertilizer for sustainable maize and cowpea yields in Nigeria, J. Plant Nut. 27(7) (2004) 1163-1181.

[8] M.I. Bajwa, F. Rehman, Soil and fertilizer potassium, in: A. Rashid, K.S. Memon (Eds.) Soil Science, National Book Foundation, Islamabad, 1996, pp. 317-338.

[9] S.M. Mian et al., Effect of MOP and SOP on plant chloride uptake and soil properties in a rice-wheat rotation, Pak. J. Soil Sci. 14(1-2) (1998) 70-74.

[10] I. Cakmak, The role of potassium in alleviating detrimental effects of abiotic stresses in plants, J. Plant Nutr. Soil Sci. 168 (2005) 521-530.

[11] M.A. Chajjro et al., Sunflower hybrids differentially accumulate potassium for growth and achene yield, Pak. J. Agri., Agril. Engg., Vet. Sci. 29(1) (2013) 31-43.

[12] D.J. Reuter, J.B. Robinson, Plant analysis: An Interpretation Manual, 2nd Indian Ed., SBS Publishers \& Distributors Pvt. Ltd., New Delhi, India, 2008.

[13] M. Aslam et al., Effect of single and combined use of various organic amendments on wheat grown over green manured soil growth and yield attributes, Pak. J. Nutr. 10 (2011) 640-646.

[14] R. Ahmad, Physio-Agronomic characteristics of semi dwarf and standard height sunflower hybrids as affected by nutritional area and potassium application, Ph.D. thesis, Department of Agronomy, UAF, Pakistan, 1993.

[15] M.T. Ramzan, Effect of different doses of potash on yield and oil content of sunflower, MSc. Thesis, Dept. of Agronomy U.A.F., 1994.

[16] A. Pervaiz, Effect of different sources and levels of potash on yield and oil content of spring sunflower (Helianthus annuus L.), M.Sc. Thesis, Dept. Agron., Univ. Agri. Faisalabad, 1996.

[17] A.U. Chaudhry, M. Mushtaq, Optimization of Potassium in sunflower, Pak. J. Biol. Sci. 2(3) (1999) 887-888.

[18] A.P. Sivamurugan, A. Balasubramanian, C.R. Chinnamuthu, Effect of N, P and K levels and seed setting treatments on yield attributing character and yield of sunflower, Madras Agric. J. 87(4/6) (2001) 291-294 
[19] Amanullah, M.W. Khan, Interactive effects of potassium and phosphorus on Phenology and grain yield of sunflower in Northwest Pakistan, Soil Sci. 20(5) (2010) 674-680.

[20] M.H. Siddiqui et al., Effect of NPK, micronutrients and N-placement on the growth and yield of sunflower, Sarhad J. Agric. 25(1) (2009) 45-52.

[21] S.A. Asadi, Influence of different K fertilizer sources on sunflower production, in: Proc. $19^{\text {th }}$ World Congress of Soil Science, Soil Solutions for a Changing World 1 - 6 August 2010, Brisbane, Australia.

[22] M.S. Brar et al., Role of potassium nutrition in nitrogen use efficiency in cereals. Research Findings of Int. Potash Institute, 2011.

[23] M.A. Khan, K. Ahmad, J. Ahmad, Effect of potassium levels on the yield of sunflower (Helianthus annuus L.), Pak. J. of Biol. Sci. 2(2) (1999) 402-403.

[24] S.A. Sadiq et al., Effect of various levels of Nitrogen, Phosphorus and potassium (NPK) on growth, yield and yield components of sunflower, Int. J. Agric. Soil. 5(1) (2000) 64-66.

[25] N. Nawaz et al., Yield and yield components of sunflower as affected by various NPK levels, Asian J. Agri. 3(7) (2003) 241249.

[26] M.A. Malik et al., Effect of nitrogen and phosphorus application on growth, yield and quality of mungbean (Vigna radiata L.), Pak. J. Agric. Sci. 40(3/4) (2004) 133-136.

[27] S. Singh, M.S. Sidhu, Integrated use of organic and inorganic fertilizer sources in hybrid sunflower Helianthus annuus L. succeeding potato Solanum tuberosum L., J. Res, Punjab Agric. Univ. 31(3) (2004) 276-279.

[28] M. Mollashahi, H. Ganjali, H. Fanaei, Effect of different levels of nitrogen and potassium on yield, yield components and oil content of sunflower, Int. J. Farming and Allied Sci. 2 (2013) 1237-1240.

[29] A.G. Soomro et al., Growth and yield of sunflower in response to planting geometry and nitrogen foliar application at various crop stages, Am. Eurasian J. Agri. Environ. Sci. 15(1) (2014) 140-146.

[30] J. Bakht et al., Effect of irrigation on physiology and yield of sunflower hybrids, Pak. J. Bot. 42(2) (2015) 1317-1326.

[31] R. Ahmad et al., Yield potential and oil quality of two sunflower hybrids as affected by K application and growing seasons, Int. J. Agric. and Biol. 3(1) (2001) 51-53.

[32] F.F. Guilherme et al., Growth and physiological responses of sunflower grown under levels of water replacement and potassium fertilization, Afr. J. Agric. Res. 11(14) (2009) 1273-1281. 